\title{
"Makam" Nasi: Language Interference of a Japanese Young Learner in Indonesia
}

\author{
Kadek Eva Krishna Adnyani ${ }^{1}$, Ni Wayan Nilam Puspawati ${ }^{2}$, Ni Komang Arie \\ Suwastini $3^{3 *}$ iD \\ 1,2,3 Universitas Pendidikan Ganesha, Singaraja, Indonesia \\ *Corresponding author:arie.suwastini@undiksha.ac.id
}

\begin{abstract}
In acquiring the second language, children will use their first language knowledge as a base in their attempt of using a new language. This phenomenon is called language interference. This study aimed at identifying specific instances of language interference conducted by a bilingual child during her study in an international school. The subject was a 5-year-old Japanese child who was acquiring Indonesian as her second language. This study was a case study using descriptive qualitative research method. Data collection was done through observation, interview and note taking. Furthermore, the data in the form of utterances in Indonesian interfered by Japanese were analyzed descriptively. The results showed that the most common type of language interference occurred was phonological interference (16 examples), followed by lexical error (4 words) and grammatical error (5 sentences). In short, in this case, Japanese phonological interference with Indonesian pronunciation occurred more frequently than lexical error and grammatical error.
\end{abstract}

Keywords: Indonesian, Japanese, Language Interference, Young Learner

$\begin{array}{ll}\text { History: } & \\ \text { Received } & \text { : September 04, } 2021 \\ \text { Revised } & \text { : September 08, } 2021 \\ \text { Accepted } & \text { : October } 10,2021 \\ \text { Published } & \text { : October } 25,2021\end{array}$

\section{INTRODUCTION}

Bilingual children are defined as children who are able to use two languages. It is not surprising that many children are known to be bilingual today. However, as children acquire two languages at the same time, the understanding of one language may influence the ability of the other language (Maheswari et al., 2020). It is because when children learn and want to speak the second language, they will rely on structures and cultures of their first language (Hadisaputra \& Adnyani, 2012; Suwastini et al., 2020). In the case of bilingual children, the family plays a vital role as a social organization to allow for the emergence of cross-cultural and cross-generational factors (Derakhshan \& Karimi, 2015; Nurjaleka \& Supriatnaningsih, 2021).

Bilingual children's increased social awareness and metalinguistic awareness may have helped them to distinguish between speakers, identify with whom they shared community membership, and create a preference for whom to copy (Atagi et al., 2015; Gyogi, 2015). The weaker language that bilingual children acquire is the language that is not spoken in their society. Furthermore, the weaker language grows more slowly and undergoes linguistic components transfer from the more dominant language (Adnyani, 2021; Adnyani et al., 2017). It is a common phenomenon when prior knowledge is used as a foundation to learn new things. The utilization of prior knowledge also applies in learning languages. That is why children will tend to attempt using their knowledge from the languages they have acquired or are acquiring in learning a new language (Amin, 2017).

This phenomenon is called as language transfer. This transferring process from the first language into the second language can be categorized into two, namely positive transfer 
and negative transfer. Positive transfer is considered to have positive impact on the second language acquisition since the first language knowledge helps building up the knowledge of the second language. On the other hand, negative transfer impacts the second language acquisitions negatively (Gass \& Selinker, 1983). Language transfer is also defined as the synonymy of language interference (It is because both are considered interchangeable. However, it is also mentioned that language interference is one of two types of language transfer (Erarslan \& Hol, 2014; Sari et al., 2021). It is because negative transfer stimulates language interference. It happens when the knowledge of the first language (L1) interferes with the use of the second language (L2). Moreover, language interference can be defined as a circumstance in which the knowledge of a speaker's or a writer's native language is applied to a second language (Alkhateeb, 2016; Kusumawardani \& Adnyani, 2020).

It is in line with the statement of Sirbu which states that language interference occurs due to the transfer of language elements of a language into other languages which have different levels of linguistics (Sirbu, 2015). Furthermore, the occurrence of language interference can be noticed in all language levels such as phonology, lexical, syntax, semantic and pragmatic (Grosjean \& Byers-Heinlein, 2018). The most common types of interference are phonological interference, lexical error and grammatical error (Chachu, 2016; Fauziati, 2017; Manik \& Suwastini, 2020; Pratiwi et al., 2020; Purnamasari et al., 2016; Suwastini \& Yukti, 2017). These interferences occur when the knowledge of a language in one aspect interferes with an aspect in other language. This is considered as a starting point of bilingualism. Since children are still in the process of language acquisition, language interference cannot be denied.

In addition, Japanese is not an unfamiliar language in Indonesia. There are many schools that teach Japanese as the third language. In line with it, Japanese students are found to take study in Indonesia as well, especially in international schools. Consequently, Japanese students must adapt with Indonesian and English to conduct daily conversation with their multinational friends. In this case, language transfer plays a crucial role. When positive transfer occur, Japanese students can utilize their Japanese knowledge to speak Indonesian since Indonesian is similar to Japanese in terms of pronunciation. However, when negative transfer or language interference occurs, Japanese will have difficulties to be understood since Japanese and Indonesian have different linguistic levels.

Japanese has a limited range of phonetics, both in their sound as well as their distribution (Thompson, 2001). Compared to English pronunciation, Japanese seems to be more closely related to Indonesian pronunciation. The way of pronouncing Japanese words and Indonesian words are similar. What is written in Japanese is read as what it is. This is also applied in Indonesian. Although they are similar, Japanese and Indonesian also have differences. Japanese has five vowels, namely /a/ /i/ / $/$ /e/ /o/. Meanwhile, Indonesian has six vowels (Yong, 2001). It includes a vowel that does not exist in Japanese: /ə/. There is no /a/ sound in Japanese and there is no authentic Japanese word that has /a/ sound in it. It results a difficulty in pronouncing $/ \mathrm{\partial} /$, especially in pronouncing Indonesian words that have numerous words with /a/ sound in it. Therefore, Japanese tend to change /a/ sound into /a/ or /u/ (Smith, 2012; Thompson, 2001). This replacement strategy is called substitution (Hasan, 2017). Another difference, furthermore, lies on pronouncing several consonants, some of which are n, ng, 1 and $r$ (Thompson, 2001). Words that have ' $n$ ' are pronounced as $/ \mathrm{n} /, \mathrm{m} /$ or /y/ by Japanese (Thompson, 2001).

For instance, 何[nan] is pronounced as /nan/ meaning 'what'; 乾杯[kanpai] is pronounced as /kampai/; and, 鞄[kaban] is pronounced as /kabay/meaning bag. These three types of ' $n$ ' sound contribute to language interference. It is because it is different from Indonesian which has clear differences among $/ \mathrm{n} / \mathrm{m} /$ and $/ \mathrm{y} /$. Furthermore, Japanese has no strict distinguish between 1 and $\mathrm{r}$. The way Japanese pronounce $/ \mathrm{l} / \mathrm{and} / \mathrm{r} /$ is found to be $/ \mathrm{l} /$ 
although some Japanese pronounce /l/ and /r/ with soft /r/ (Nogita, 2010; Smith, 2012; Thompson, 2001).

Japanese structure, on the other hand, can be considered similar to Indonesian. It is said to be similar since Japanese structure is as free as Indonesian, especially in the spoken form of informal communication (Thompson, 2001). Nevertheless, there is a significant difference in the basic structure between Japanese and Indonesian. In Indonesian, the basic structure of an utterance is subject + verb + object. In Japanese, on the other hand, the basic structure is subject + object + verb (Thompson, 2001). This different structure leads to language interference with Indonesian.

Bilingual acquisition by very young children (i.e., Japanese and another language) is currently an understudied subject in the bilingual study (Kutsuki, 2021). There are many studies investigating the occurrence of language interference among languages. Nevertheless, as best to the author's knowledge, there is no study on language interference conducted by Japanese-Indonesian bilingual children yet. Therefore, language interference occurrence on other language pairs would be taken a look at. In the case of Japanese as the first language, It was found that most errors occurred due to Japanese interference, especially in terms of phonological interference, morphological and syntax interference, and lexical interference (Kroll, 2011; Nogita, 2010; Sarif S \& Suganda, 2020). Participants of this study tended to apply their Japanese pronunciation knowledge when pronouncing L2 words.

Furthermore, in a study conducted by Bhela, there were four bilinguals with different first languages observed in terms of their writing interference. It was found that there were similarities and differences on language interference among the participants (Bhela, 1999). Besides, Alkhateeb observed Arabic language interference on English (Alkhateeb, 2016). It was found that interference occurred more frequently in terms of phonological interference and grammatical error. Arabians tend to pronounce English words based on Arabic pronunciation. Moreover, English grammatical structure was found to be influenced by Arabic structure (Alkhateeb, 2016). Erarslan and Hol found Turkish interference occurs on the second language in terms of vocabulary use, preposition use, and present tense use (Erarslan \& Hol, 2014). As a result, it can be concluded that first language (L1) knowledge plays a crucial influence on second language (L2) use.

Previous studies have reported that in the case of Japanese as the second language, the interferences that appear when learning Japanese by students are interferences in syntax, phonetics, and morphology (Harisal, 2021; et al., 2019). Also, It was found that the grammatical aspect and borrowing aspect influence the learner's L1 (Aziz et al., 2019). Other author, discuss the lexical interference of Bataknese language into Japanese language and discovered that the most dominant interference that occurred is noun interference (Pujiono \& Nelvita, 2017).

This project will provide a significant opportunity to advance the understanding of the development of bilingual learning for young learners. Based on the explanation above, other languages are found to interfere with the second languages. It stimulates a question regarding whether or not Japanese language interferes with Indonesian language especially when it is conducted by a child. Specific instances as well as the types of language interferences are also essential to be known. Due to the fact that Japanese and Indonesian are similar yet also different in their linguistic aspects, studies regarding this case are essential to be conducted. Therefore, this study focused on observing Japanese language interference conducted by a Japanese young learner in speaking Indonesian. The objective of the study was to find out specific instances of Japanese language interference on Indonesian language conducted by a bilingual young Japanese learner. As a result, the research question was formulated as: what are specific instances of language interferences conducted by a Japanese bilingual child in speaking Indonesian? 


\section{METHODS}

This study was a qualitative case study. As the aim of the study was to find specific instances of Japanese language interference with Indonesian language, qualitative research was appropriate to be conducted. The study only focused on one bilingual child in order to gain better understanding of a phenomenon, in this case was the occurrence of language interference, in the second language acquisition process. The subject of the study is a 5-yearold Japanese child. The subject is assigned as a student at Trihita Alam Eco School, an international school located in Sidakarya, Bali since July, 2019. She comes from Japan and her parents are native Japanese without any mixed blood. As a result, the subject's first language (L1) is Japanese; her second language (L2) is Indonesian; and her third language (L3) is English. Even though the subject is acquiring three languages at the same time, she cannot be categorized as multilingual yet since she passively understands and rarely uses English. Therefore, the subject is labeled as a bilingual child because she speaks both Japanese and Indonesian.

Furthermore, she has been a student since the first semester of school in the academic year 2019/2020. In the first two months of her study in Bali, she was unable to communicate well with anyone other than one specific teacher, in this case is the author, who knows Japanese. Nevertheless, in her third month of schooling, her Indonesian started to develop as she was eventually able to say some phrases and basic sentences in Indonesian. In her acquisition process, Japanese language interference occurred with Indonesian language when she communicated. The data were obtained through observation and interview. The subject was observed for five days in a week starting from Monday until Friday and in two hours per day at the school playground after her school time. At this time, the subject's communication was observed to collect examples of language interference in her spontaneous and natural conversation. Due to the rule of the school which does not allow the use of smartphones during working hours, the conversations were not possible to be recorded. Therefore, notetaking method was used. In addition, there were two teachers and two teacher assistants who taught in the subject's class. These four teachers were interviewed twice within the purpose to know specific instances of language interference conducted by the subject in the teaching and learning process. The questions were given in the form of open-ended questions during break time to avoid formal atmosphere. As a result, the answers of the interviews could be gathered without any force to please the author. The data were analyzed by considering all interferences as examples. For phonological interference, Indonesian phonemes were used to find the interference.

\section{RESULTS AND DISCUSSION}

\section{Result}

The results of the analysis revealed that although the subject studied in an international school, she had not been able to acquire English as fast as acquiring Indonesian. Based on the observation and interviews, it was found that three levels of language interference occurred. The following is the graphic presenting the numbers of specific instances of language interference based on their types as shown in Figure 1. 


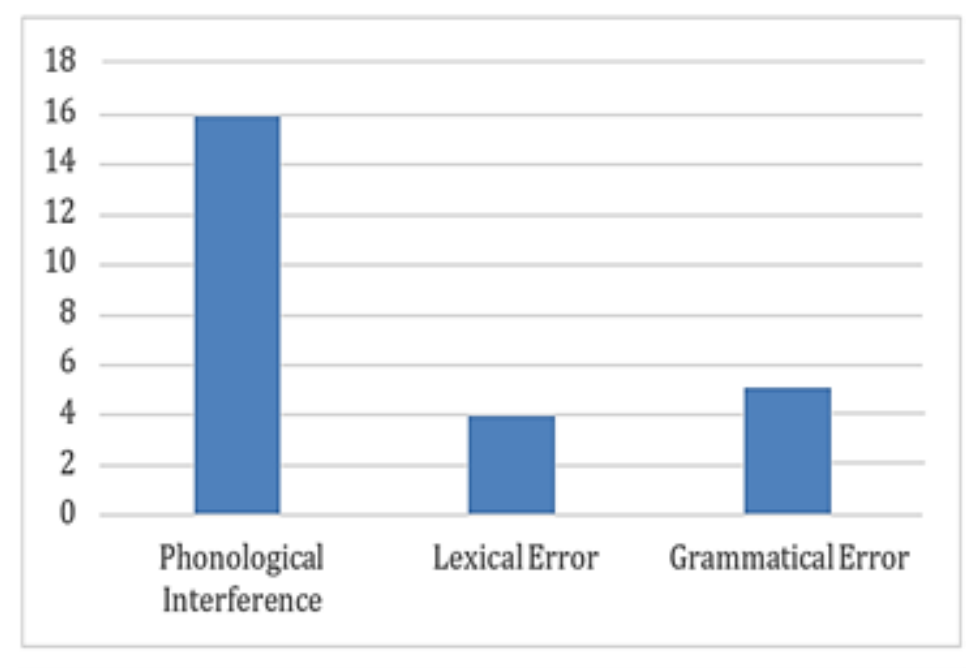

Figure 1. Numbers of specific instances of Japanese interference with Indonesian

Figure 1 shows that the interferences occurred in the subject's utterances were phonological interference, lexical error, and grammatical error. There were 16 words containing phonological interferences, 4 lexical errors and 5 grammatical error in terms of word order. This phenomenon occurs due to the emergence of language transfer. Positive transfer enables The subject to speak Indonesian better than English. It is because Japanese and Indonesian have similarities in pronunciation. The sounds of most Indonesian letters have the same sounds as in Japanese. Thus, the subject was able to utilize her prior knowledge of Japanese pronunciation when she spoke Indonesian. In addition, flexible sentence structures in informal Indonesian promotes the subject's speaking confidence. She did not seem to be as shy as when she was asked to speak English. Moreover, the subject was still a child so that her communicative process did not require complex structure. During her conversations, the subject uttered simple sentences containing several repeated words. However, negative transfer also cannot be avoided. It triggers interference in some aspects of linguistics. The aspects that made the subject able to speak Indonesian were also interfered in her acquisition process.

\section{Discussion}

\section{Japanese phonological interference with Indonesian pronunciation}

Since the subject started to acquire Indonesian in her third month of schooling, her vocabulary knowledge was still limited. Moreover, The subject was five years old so that her topic of communication did not require complex word choices. The subject mostly communicated with her school friends whose mother tongue was Indonesian or whose second language was Indonesian. She avoided communication with her friends whose mother tongue was English and did not know Indonesian words. During here conversations, there were four phonological interferences found. From the data obtained, there were mispronunciations found in the utterances of the subject. The words that have /a/ sounds, end in $/ \mathrm{n} /$, have $/ \mathrm{y} /$ sound, and have /l/ and /r/ sound were pronounced differently. Based on the analysis, the different ways of pronunciation occurred as the subject applied her Japanese knowledge in speaking Indonesian. Therefore, it implied that Japanese pronunciation interfered with her Indonesian pronunciation. It proves that the types of phonological interference identified by previous researchers (Smith, 2012) also occurred in the subject's case. Table 1 shows that the pattern of the substitution was consistent. Japanese has no /ə/ sound which makes Japanese people change the absent sound into other sounds (Schecter, 1988; Smith, 2012). In this case, the subject changed her /ə/ into /u/. It can be seen from the way the subject pronounced three 
words which had /ə/ sound in them. The subject applied her prior Japanese pronunciation knowledge of the absent sound. Instead of trying to pronounce $/ \partial /$, she used $/ u /$ as the substitution.

Table 1. Japanese Phonological/ə/ interference with Indonesian Pronunciation

\begin{tabular}{cccc}
\hline No & Word & $\begin{array}{c}\text { Indonesian } \\
\text { Pronunciation }\end{array}$ & $\begin{array}{c}\text { Phonological } \\
\text { Interference }\end{array}$ \\
\hline 1. & $\begin{array}{c}\text { semut } \\
\text { 'ant' } \\
\text { belum } \\
\text { 'not yet' } \\
\text { kecil } \\
\text { 'small' } \\
\text { jelek } \\
\text { 'bad' }\end{array}$ & /somut/ & $/$ /bolum/ \\
4. & /kocil/ & $/ \mathrm{bulum} /$ \\
& /jolek/ & $/ \mathrm{kucil} /$ \\
\hline
\end{tabular}

The word sumut must be pronounced as semut /səmut/ means 'ants'. This mispronunciation occurred every time the subject referred to ants although she had been told the correct pronunciation. Two conversational examples conducted by the subject with her friends and teachers are shown in (1) and (2) as follows:

(1) Classmate : Jangan pegang itu. Nanti gatal. (Do not touch it. You will be itchy!")

The subject : Oh iya, itu banyak sumut. (Oh right, those are many sumut.)

Classmate : Iya, semut. (Yes, ants.)

The subject : Sumut? (Sumut?)

Example (1) occurred when the subject was playing with her friends after school. The conversation occurred due to the presence of ants near a tree where they were playing. The subject was warned by her friend. When the subject was warned, she realized that the lexical word for 'ants' is semut. However, due to her prior pronunciation knowledge, she pronounced it as /sumut/ instead. She was explicitly corrected by her friend; nevertheless, the subject was seemed to be unaware that her Japanese interferes with Indonesian.

(2) The subject : Miss, sini lihat! (Miss, come here, look!)

Teacher :Ada apa?(What happened?)

The subject : Saya bawa sendok kucil. (I am bringing small kucil spoon)

Teacher : Itu kecil. Coba bilang kecil. (It's small. Try saying kecil.)

The subject : Kucil (Kucil.)

Example (2) occurred after school the other day. The subject was getting ready to eat. As she opened her utensil, she called the author to show what she brought. While showing the spoon, she pronounced the word kecil / kəcil/ as /kucil/ 'small'. The teacher attempted to ask the subject to pronounce correctly. At this moment, the teacher corrected the subject directly. She realized her error, yet she still pronounced it /kucil/. The interview with her classroom teachers revealed that the subject was not an active student in the classroom. Due to her language and vocabulary limitation, the subject avoided communication in the classroom. The teachers said that the interference that mostly occurred and were noticed were 'kucil' and 'bulum'. The appropriate pronunciation is /kəcil/ meaning 'small', yet the subject pronounced it 'kucil' /kucil/ which has no meaning in Indonesian. Furthermore, another word 
noticed was 'bulum'. It should be pronounced as /bəlum/ meaning 'not yet'. The subject, on the other hand, pronounced it as /bulum/ which has no meaning in Indonesian.

These findings, therefore, are similar with the previous studies on Japanese interference with English. It proved the studies of previous studies that Japanese has difficulty in pronouncing /a/ sound (Smith, 2012). The unavailability of /a/ sound in Japanese vowel establishes no prior knowledge regarding the sound. Due to this issue, the subject repeatedly used her Japanese pronunciation knowledge to change /a/ to the closest sound to make it similar. In this case, the subject chose to replace /ə/ with $/ \mathrm{u} /$. This strategy is called as substitution which means that the speaker replaces sounds of the target language (Hasan, 2017). As a result, it can be said that Japanese do not only use this substitution strategy when they attempt to speak English, but also when they attempt to speak Indonesian.

Table 2. Japanese Phonological /n/ interference with Indonesian Pronunciation

\begin{tabular}{cccc}
\hline No & Word & $\begin{array}{c}\text { Indonesian } \\
\text { Pronunciation }\end{array}$ & $\begin{array}{c}\text { Phonological } \\
\text { Interference }\end{array}$ \\
\hline 1. & Makan 'eat' & $/$ makan/ & $/$ makam/ \\
2. & Minum 'drink' & /minum/ & $/$ minun/ \\
3. & Nonton 'watch' & /nonton/ & /nonton/ \\
\hline
\end{tabular}

The second finding is the interference in terms of pronouncing words ending in $/ \mathrm{n} /$. There are three patterns found since Japanese pronounce words ending in $/ \mathrm{n} /$ with three different ways. The patterns are found to be the same as Japanese pronunciation: $/ \mathrm{n} / \mathrm{sound}$ is changed into $/ \mathrm{n} /, / \mathrm{m} /$ and $/ \mathrm{y} /$. The patterns of interference regarding words ending in $/ \mathrm{n} / \mathrm{can}$ be seen in examples (3) to (5)

(3) The subject : "Miss, sekarang makam ya?" (Miss, is it grave now?)

Teacher : "Eh, makam apa?" (Err, what grave?)

The subject : "Makam nasi." (Grave rice)

Teacher : "Makan? Iya ayo makan." (Eat? Yes, let's eat.)

The subject : "Iya, makan." (Yes, eat.)

In Example (3), the subject asked whether it was lunch time or not. Instead of asking whether it was 'eat' time, she asked about 'grave' time. Her first language knowledge interferes with Indonesian language in terms of pronouncing words ending in $-n$ as $/ \mathrm{m} /$. Instead of pronouncing the word maka' as /makan/ meaning 'eat', it was pronounced as /makam/ meaning 'grave'. As a result, it can be said that the use of first language knowledge in an attempt to pronounce words in the second language also leads to different meanings. This finding is in line with the studies of Alkhateeb (2016), Nogita (2010), Smith (2012), and Thompson (2001), which found that language interference in terms of phonological interference can stimulate confusion. However, the availability of $/ \mathrm{n} /$ sound in Japanese does not struggle the subject to correct her pronunciation. It was seen from the way she changed the pronunciation /makam/ into /makam/ when the author explicitly corrected her.

(4) The subject : "Miss, saya mau minun." (Miss, I want to drink.)

Teacher : "Eh, kok minun? Kamu mau minun apa?" (Err, why minun? What do you want to minun?)

The subject : "Minun." (Minun)

Teacher : "Itu minum. Coba bilang minum." (It's minum/ drink. Try to say minum.)

The subject : "Minum." (Drink) 
Example (4) occurred during the observation after school. The subject asked for her teacher's permission to go to her classroom to drink some water. Nevertheless, she conveyed her intention by saying 'minun' /minun/ instead of 'minum' /minum/ which means 'drink'. In fact, /minun/ has no meaning in Indonesian. Unlike the previous word in which $-\mathrm{n}$ as the ending of the word was pronounced as $/ \mathrm{m} /$, the subject reversely pronounced a word ending as $-\mathrm{m}$ as $/ \mathrm{n} /$. Japanese has no word ending in $/ \mathrm{m} /$. The sound $/ \mathrm{m} /$ is pronounced before consonant $/ \mathrm{b} /$ and $/ \mathrm{p} /$. In writing a word that has $/ \mathrm{m} /$ sound, Japanese will use letter ' $\mathrm{n}$ '. Therefore, the confusion between the use of $/ \mathrm{n} /$ and $/ \mathrm{m} /$ sound is understandable. Since pronouncing $/ \mathrm{m} /$ is also a pattern of Japanese pronunciation, it is not problematic for the subject to correct her pronunciation after being corrected by her teacher.

(5) The subject : "Saya tahu lagu ini." (I know this song.)

Teacher : "Lagu apa ini?" (What song is this?)

The subject : "Lagu Aladin. Saya nontong sama mami." (Song of Aladin. I nontong/watched it with mommy.)

Teacher : "Nonton sama siapa lagi?" (Whom else you watched with?)

The subject : "Saya nonton sama mami sama Hana." (I watched it with mommy and Hana).

Example (5) shows another phonological interference. The way the subject pronounced the word nonton 'watch' as /nontong/ when it supposed to be /nonton/. This is another type of $/ \mathrm{n} /$ sound in Japanese. Japanese tend to pronounce words ending in $/ \mathrm{n} / \mathrm{as} / \mathrm{y} /$ (Thompson, 2001). The $/ \mathrm{y} /$ sound is found to be more common produced by Japanese at the end of the words. As well as the other types of $/ \mathrm{n} / \mathrm{sound}$, the subject did not find difficulty in correcting her pronunciation. These findings regarding Japanese phonological interference with Indonesian in terms of pronouncing words ending in $/ \mathrm{n} /$ proved the study of Nogita (2010), Smith (2012), and Thompson (2001). Unlike the interference occurred on /u/ sound that stayed constant and stable, phonological interference in terms of words ending in $/ \mathrm{n} / \mathrm{was}$ found to vary. The availability of three $/ \mathrm{n} /$ sound patterns play crucial roles in Japanese interference with Indonesian. The subject utilized her Japanese knowledge regarding three patterns of $/ \mathrm{n} /$ sound into her attempt in communicating in Indonesian. Since the sounds were familiar to Japanese speakers, the subject was able to correct her pronunciation although the corrections were explicitly delivered. Another Japanese phonological $/ \mathrm{y} /$ interference with Indonesian pronunciation were also identified as seen in table 3.

Table 3. Japanese Phonological / $\mathrm{y} /$ interference with Indonesian Pronunciation

\begin{tabular}{cccc}
\hline No & Word & $\begin{array}{c}\text { Indonesian } \\
\text { Pronunciation }\end{array}$ & $\begin{array}{c}\text { Phonological } \\
\text { Interference }\end{array}$ \\
\hline 1. & Hidung 'nose' & /hiduy/ & $/$ hidum/ \\
2. & Kurang 'less' & /kuray/ & $/$ kuram/ \\
3. & Jangan 'do not' & /janan/ & $/$ jangan/ \\
4. & Tangan 'hands' & /tanan/ & /tangan/ \\
\hline
\end{tabular}

The examples of words shown in Table 3 were in in line with the interference shown in Table 2. In Table 2, the subject substituted $/ \mathrm{n} / \mathrm{with} / \mathrm{y} /$ yet in this case, she substituted $/ \mathrm{y} /$ with $/ \mathrm{n} /$. The examples of the interference can be seen in example (6) as follows.

(6) Teacher : "Bahasa Jepang ini apa?" (What is this in Japanese?")

The subject : *avoided speaking Japanese*

Teacher : :Bahasa Jepang ini ohana, bahasa Indonesia itu hidung. Coba bilang 
hidung." (It's ohana in Japanese, in Indonesian it's hidung/nose. Try to say hidung.)

The subject : "Hidum" (Hidum)

Teacher : "Iya." (Yes.)

The subject : "Sudah tahu hidum." (Already know it's hidum).

In example (6), the author played a guessing game with the subject after school as a means of communication. When she was asked the Japanese word for nose, the subject chose to remain silent. As explained, the subject seemed to be more confidence when speaking Indonesian rather than Japanese. When she was asked personally by the author, the subject admitted that she was shy. Therefore, she chose not to answer the Japanese word for nose. Furthermore, the author kept on the conversation by telling the Japanese word as well as the Indonesian word for nose. The subject was asked to repeat saying hidung meaning 'nose'. An mispronounced the $/ \mathrm{y} /$ into $/ \mathrm{m} /$ sound. It was due to her Japanese phonological interference.

The way the subject replaced the sound of $/ \mathrm{y} /$ into $/ \mathrm{m} /$ also occurred when she pronounced 'kuram' /kuram/ for 'kurang'/kuray/ meaning 'less'. This phenomenon was revealed from the interviews with the teachers. It was acknowledged that the subject had difficulty and confusion in pronouncing 'kurang'. When she was corrected explicitly, the subject did not realize her error. However, when she was given direct corrections, the subject was found to be able to adapt with the $/ \mathrm{m} /$ sound. She was able to pronounce kurang $/ \mathrm{kuray} /$ instead of 'kuram' /kuram/. In addition, since the subject also had the knowledge that $/ \mathrm{n} / \mathrm{can}$ be pronounced as $/ \mathrm{y} /$, the subject pronounced jangan /janan/ meaning 'do not' as 'janggan' /jangan/. Although the subject was corrected several times by her teachers, she still pronounced it as /jangan/ instead of /jangan/. Moreover, this type of interference also occurred when she referred to her hands. The subject kept pronouncing /tangan/ for tangan which should be pronounced as /tangan/ meaning 'hands'. The other common phonological interference occurred in terms of pronouncing $/ 1 /$ and $/ \mathrm{r} /$ as shown in table 4 .

Table 4. Japanese Phonological /1/ and /r/ interference with Indonesian Pronunciation

\begin{tabular}{cccc}
\hline No & Word & $\begin{array}{c}\text { Indonesian } \\
\text { Pronunciation }\end{array}$ & $\begin{array}{c}\text { Phonological } \\
\text { Interference }\end{array}$ \\
\hline 1. & Air 'water' & /air/ & /ail/ \\
2. & Rambut 'hair' & /rambut/ & /lambut/ \\
3. & Rusak 'broken' & /rusak/ & $/$ melah/ \\
4. & Merah 'red' & $/$ merah/ & /aulola/ \\
5. & Aurora 'Aurora' & /aurora/ & \\
\hline
\end{tabular}

Table 4 shows phonological interference occurred in terms of pronouncing $/ \mathrm{l} /$ and $/ \mathrm{r} /$. The subject was also found to conduct this phonological interference. She tended to pronounce words ending in $/ \mathrm{r} /$ as ending in $/ 1 /$ as seen in example (7).

(7) The subject : "Miss, saya mau isi ail." (Miss, I want to refill the water)

Teacher : "Coba bilang air dulu." (Please say air/water first.)

The subject : "Ail." (Ail / water.)

Example (7) shows that pronouncing words ending in $/ \mathrm{r} /$ was difficult for the subject. As same as most Japanese, the substitution of $/ \mathrm{r} /$ into /l/ was done [13]. This finding was supported by the results of the interviews with the subject 's teachers. It was found that the subject pronounced rambut/rambut/ meaning 'hair' as /lambut/; rusak /rusak/ meaning 'broken' as /lusak/; merah /merah/ meaning 'red' as /melah/; and, 'aurora' /aurora/ as 
/aulola/. Although the subject was corrected directly, it was problematic to pronounce strong $/ \mathrm{r} /$ sound. Nevertheless, phonological interference in terms of $/ 1 /$ and $/ \mathrm{r} /$ sounds did not establish misunderstanding.

\section{Lexical Interference}

There are four examples of most noticeable lexical interference conducted by the subject. All of the interferences occurred due to misinterpret and mistranslation between her Japanese knowledge and Indonesian context. Misinterpretation and mistranslation occurred because the subject still had limited Indonesian vocabulary as well as limited knowledge regarding Indonesian context. The examples of Japanese lexical interference with Indonesian can be seen in the table 5 .

Table 5. Japanese Lexical Interference with Indonesian Word

\begin{tabular}{cccc}
\hline No. & Lexical Interference & $\begin{array}{c}\text { Japanese Word it } \\
\text { interferes with }\end{array}$ & $\begin{array}{c}\text { Appropriate } \\
\text { Indonesian Word }\end{array}$ \\
\hline 1. & jorok & 悪い & jelek \\
(disgusting) & (warui /bad) & imut \\
(cute) \\
2. & cantik & 可愛い & ganteng \\
& (beautiful) & (kawaii / cute) & 可愛い \\
3. & cantik & (kawaii / cute) & lihat \\
& (pretty) & 見る & (see) \\
\hline
\end{tabular}

The findings listed in the table 5 show that meanings in Japanese can interfere with meaning in Indonesian. Since one word in Japanese has several similar translation in Indonesian, confusion regarding which word choices to use emerges. The subject used her Japanese knowledge in which she used Indonesian vocabularies that she knew and adopted Japanese context. It resulted wrong word choices which lead to confusion of the interlocutor. The conversations where lexical interference occurred can be seen in examples (8) to (11).

(8) The subject : "Saya tidak mau pakai ini ya." (I do not want to use this.)

Teacher : "Kenapa? Ini bagus." (Why? This is good.)

The subject : "Ini jorok." (This is disgusting.)

Teacher : "Apanya jorok? Tidak kotor." (What is disgusting? It is not dirty.)

The subject : "Tidak mau pakai melah. Jorok." (I do not want to use red. Disgusting.)

Teacher : "Maksud kamu jelek ya?" (Do you mean bad jelek?)

The subject : "Hah, apa itu julek?" (Huh, what is julek?)

Teacher : "Jelek itu tidak bagus." (Jelek means not good.)

The subject : "OOh, iya tidak bagus." (Oh, yes, not good.)

In example (8), the subject showed her Japanese knowledge utilization to convey her intention. In this situation, the subject rejected using a red crayon to write her name. This is a surprising phenomenon in which the subject also used her Japanese cultural knowledge. In Japanese culture, writing names in red means bad luck (Benton, 2016). As a result, the subject avoided red crayon to write her name. Nevertheless, in conveying her intention, the subject used jorok which means 'disgusting' to state that red is not good for writing names. The word jorok can also be said as 悪い warui in Japanese. Since the subject has limited vocabulary, she chose to translate warui into 'disgusting' jorok instead of 'bad' jelek. This 
error in determining word choices leads to misunderstanding of the interlocutor. Meanwhile, what the subject attempted to imply was jelek 'bad'. Therefore, to avoid misunderstanding and establish a clearer perception, the author translated the word into Japanese. The aim of it was to draw the same perception of meaning that referred to by the subject. Moreover, other example of phonological interference was found in this case. As explained in the phonological interference, it is challenging for Japanese to make /ə/ sound. Therefore, the subject pronounced jelek that must be /jəlek/ as 'julek'/julek/ which has no meaning in Indonesian. It proved that $/ \mathrm{a} /$ sound still has a prominent role in phonological error. Besides, the subject also pronounced merah $/ \mathrm{merah} /$ as $/ \mathrm{melah} /$. This is in line with the findings of Nogita (2010) that Japanese tend to pronounce $/ \mathrm{r} /$ as $/ \mathrm{l} /$.

(9) Teacher : : "Kenapa kamu cantik sekali?" (why do you look so beautiful?)

The subject : "Miss juga cantik." (Miss is also beautiful.)

Teacher : "Kamu juga imut. Miss ingin imut seperti kamu." (You are also cute. Miss wants to be as cute as you.)

The subject : "Apa itu imut?" (What is cute?)

Teacher : “Imut itu kawaii." (Cute is 可愛い 'kawaii')

The subject : “Kawaii itu cantik.” (可愛い is beautiful)

Teacher : "Bukan, cantik itu kirei.” (no, beautiful is 綺麗.)

The subject : "Bukan, cantik itu kawaii. Saya mau cantik, mau kawaii bukan imut." (no, beautiful is 可愛い. I want to be beautiful, want to be 可愛い not cute.)

Example (9) shows that lexical interference plays a role in the concept of word. In this case, the subject did not have knowledge about the meaning of 'cute'. Therefore, she used 'beautiful' cantik to refer to 'cute' imut. To draw a better understanding, the author translated the word 'cute' into. Japanese word that is 可愛い kawaii. However, due to her limited vocabulary and limited knowledge about 'cute', the subject denied the translation given by the author. In Japanese, kawaii can be translated into cantik yet its literal translation is 'cute'. In Indonesian context, therefore, 'cute' is defined as adorable. Thus, in this case, limited vocabulary caused lexical interference because the subject used her Japanese knowledge to convey her meaning in Indonesian.

(10) The subject : "Miss, Rocco cantik." (Miss, Rocco is pretty.)

Teacher : "Siapa? Rocco?" (Who? Rocco?)

The subject : "Iya, Rocco cantik." (Yes, Rocco is pretty.)

Teacher : "Cantik itu kirei. Hansamu itu ganteng. Cowok itu ganteng. Cewek itu cantik.” (Pretty is 綺麗 [kirei]. ハンサム [hansamu] is handsome. Boys are handsome, girls are pretty.)

The subject : "Iya, tahu. Rocco cantik." (Yes, I know. Rocco is pretty.)

Conversation in example (10) occurred spontaneously when the subject was playing with her friend, Rocco. the subject suddenly came to the author and said that her friend was pretty. Her friend was a boy. The error in choosing the appropriate identifier occurred due to two possible reasons. First, it was because the concept of boys and girls or gender identity concept is still unclear for the subject. Second, it was because she wanted to convey that Rocco was 'cute', yet as explained in (9), the subject conducted lexical interference. Based on her last statement saying Iya, tahu. Rocco cantik. which means 'Yes, I know. Rocco is pretty.", it shows that the subject understood that Rocco is a boy. Nevertheless, she kept 
saying that he was pretty. This case, therefore, is the same as (2) in which the subject intended to convey that Rocco was 'cute', not 'handsome'.

(11) Teacher : "Di Jepang ada aurora?" (Is there any aurora in Japan?)

The subject : "Tidak. Di Indonesia ada?" (No. Is there any in Indonesia?)

Teacher : "Tidak ada." (No, there is not.)

The subject : "Miss pernah nontong aulola?" (Miss, have you ever watched aulola before)

Teacher : :Nonton? Pernah." (Watched? Yes, I have.)

The subject :"Nontong dimana?" (Where did you watch it?)

Teacher : "Di TV" (On the Television.)

The subject : "Eh, tidak. Nontong itu, nontong sekarang." (Eh, no. Watch is that, watch now)

Teacher : :"Lihat langsung maksudnya?” (Do you mean 'see'?)

The subject : "Kenapa 'lihat'?" (Why see?)

Teacher : “Maksud kamu 'miru' ya? 'Mita' ya?” (You mean miru [見る], right? Mita [見た], right?)

The subject : “Iya, “mita”". (Yes, mita [見た].)

Teacher : "Oh, belum." (Oh, not yet.)

Example (11) shows lexical interference which occurred due to the various meanings of a Japanese word. A misunderstanding occurred because the subject pronounced the word nonton as /nontong/ to refer to 'see'. In Japanese, the word '見る' [miru] has several meanings both in Indonesian. “見る' [miru] means lihat 'to see' or 'to look' and nonton 'to watch'. These translations of '見る' confused the subject to determine her word choice. During the observation, the subject only used lihat as a meaning of 'see' in a command. Therefore, it can be concluded that the subject acknowledged lihat 'see' as '見て' which is used to give a command in Japanese. That was why she picked up nonton that she pronounced as 'nontong' to ask the question. This word choice leads to misinterpretation. Therefore, the author replied that she watched aurora on the television. The subject then attempted to correct what she meant. The gap between what she wanted to say and the vocabulary used was revealed. Furthermore, the author used direct translation to Japanese to understand what the subject actually wanted to ask. When the author said 見た [mita] which means 'saw', 'looked' and 'watched', it was found that the subject actually referred to 'see'. Furthermore, phonological interference still could not be avoided by the subject. In the example (11), phonological interference influenced the way the subject pronounced 'nonton' as /nonto/y/ and aurora as /aulola/. These two types of phonological interference were discussed above in the phonological interference findings.

\section{Grammatical Error}

Grammatical error occurs due to first language structure interferes with second language structure. The main word order of Japanese is subject + object + verb (Thompson, 2001). Indonesian, on the other hand, is subject + verb + object which makes it same as English (Yong, 2001). There were five grammatical errors conducted by the subject during observation. It occurred due to her attempts to adopt Japanese structure into Indonesian context as can be seen in example (12).

(12) Permisi, saya minun ail butuh.

'Excuse me, I drink water need to'. 
すみません、私はお水を飲むのが必要があります。

[Sumimasen, watashi wa omizu o nomu no ga hitsuyou ga arimasu.]

In example (12), the subject was about to take her water bottle in her classroom when the author was blocking her way in. This spontaneous permission asking showed a grammatical error, specifically in the word order. Instead of saying: Saya butuh minum air 'I need to drink water' which has the pattern of subject + verb + object, she said: Saya minun ail butuh 'I drink water needs to'. The subject used Japanese structure to build her sentence. This structure is grammatically correct in Japanese when it is translated into すみません 私はお水を飲むのが必要があります. However, the sentence is uncommon to be said in Indonesian. This proved that Japanese word order had significant impacts on language interference in terms of grammatical error. Besides, phonological interferences were found. Although An was corrected, she kept repeating the interference.

Other grammatical errors was also shown in examples (13) to (16).

(13) Miss, saya lihat ya

'Miss, I look at, okay?'

先生、私に見てね。

[Sensei, watashi ni mite ne.]

(14) Nanti saya ke Jepang pulang mau. 'Someday, I to Japan want to return.'

いつか日本に帰るのが欲しい。

[Itsuka Nihon ni kaeruno ga hoshii.]

(15) Saya makan sudah

'I eaten have'

私は食べたことがあるよ。

[Watashi wa tabeta koto ga aruyo.]

(16) Kok Miss bahasa Jepang bisa bilang?

'Why Miss Japanese can speak?'

なぜ先生は日本語を話すことが出来ますか?

[Naze -sensei wa Nihongo o hanasu koto ga dekimasuka.]

The other four findings of grammatical errors occurred in the same pattern. It was the word structure of Japanese that interferes with Indonesian structure. These findings of grammatical error did not occur as frequently as phonological interference. Although the utterances were still understandable, grammatical errors conducted by the subject were uncommon to be used in Indonesian context.

\section{CONCLUSION}

In the case of Japanese as the first language, It was found that most errors occurred due to Japanese interference, especially in terms of phonological interference, morphological and syntax interference, and lexical interference. The findings that we have presented suggest that the most frequent interference was phonological interference. Interestingly, the interferences occurred due to the unavailability of sounds in Japanese and the misunderstanding of the subject. A possible explanation for this might be related to theories 
of cognitive development. If the debate is to be moved forward, a better understanding of cognitive development theories concerning the young bilingual learner needs to be developed. This finding provides important insights into the understudied world of Japanese bilingual young learners, especially with the Indonesian Language as L2. However, a limitation of this study is that the numbers of research subjects were relatively small. These findings suggest several courses of action for language teachers, parents, and further researchers. Teachers are suggested to be aware of language interference to deliver materials and emphasize certain aspects to reduce language interference. Parents are invited to guide bilingual children and plant the appropriate primary language concepts since they are young. As for further researcher, a greater focus on phonological interference with longer observation time, bigger size of subjects and more sophisticated research methods could produce interesting findings that account more for the development of the bilingual study.

\section{REFERENCES}

Adnyani, N. L. P. S. (2021). Cross- Linguistic Influence on a Bilingual Child's Phonological $\begin{array}{llll}\text { Development. } & \text { 546(Conaplin 367-373. }\end{array}$ https://doi.org/10.2991/assehr.k.210427.056.

Adnyani, N. L. P. S., Beratha, N. L. S., \& Suparwa, I. N. (2017). Child comprehension of adults' verbal inputs a case of bilingual acquisition in infancy. Indonesian Journal of Applied Linguistics, 7(1), 11-18. https://doi.org/10.17509/ijal.v7i1.6853.

Alkhateeb, M. M. A. (2016). My mother tongue pulls my leg Arabic language interference in the acquisition of English language: An attempt to know. Journal of Education and Practice, 7(23), 96-102. https://eric.ed.gov/?id=EJ1112781.

Amin, A. A. (2017). Linguistic Analysis of the Phenomenon of Language Transfer. IOSR Journal of Humanities and Social Science, 22(04), 32-35. https://doi.org/10.9790/0837-2204043235.

Atagi, N., Goldenberg, E. R., \& Sandhofer, C. M. (2015). Children's use of linguistic information when learning in a bilingual context. https://www.sciencedirect.com/science/article/pii/S0022096515002787.

Aziz, Z. A., Daud, B., \& Yunidar, S. (2019). Second language interference towards first language use of Japanese learners. Indonesian Journal of English Language Teaching and Applied Linguistics, 4(1), 159-176. http://dx.doi.org/10.21093/ijeltal.v4i1.410.

Bhela, B. (1999). Native language interference in learning a second language: Exploratory case studies of native language interference with target language usage. International Education Journal, $\quad 1(1), \quad 22-31$. http://citeseerx.ist.psu.edu/viewdoc/download?doi=10.1.1.133.6401\&rep=rep1\&type= pdf.

Chachu, S. (2016). "I am speaking French but I am thinking in English": An analysis of errors by students of the French language at the University of Ghana. Ghana Journal of Linguistics, 5(1), 37. https://doi.org/10.4314/gjl.v5i1.73.

Derakhshan, A., \& Karimi, E. (2015). The Interference of FL and SL. Theory and Practice in Language Studies, 5(10), 2112-2117. http://dx.doi.org/10.17507/tpls.0510.19.

Erarslan, A., \& Hol, D. (2014). Language interference on English: Transfer on the vocabulary, tense and preposition use of freshmen Turkish EFL learners. ELTA Journal, 2(2), 4-22. http://eltajournal.org.rs/wp-content/uploads/2014/12/IVLanguage-interference-on-English-transfer-on-the-vocabulary-tense-and-prepositionuse-of-freshmen-Turkish-EFL-learners-by-Ali-Erarslan-and-Devrim-Hol.pdf.

Fauziati, E. (2017). Native and target language influence on the students' interlanguage productions a case of Indonesian EFL compositions. Indonesian Journal of Applied 
Linguistics, 7(1), 54-63. https://doi.org/10.17509/ijal.v7i1.6858.

Grosjean, F., \& Byers-Heinlein, K. (2018). Bilingual adults and children: A short introduction. The Listening Bilingual: Speech Perception, Comprehension, and Bilingualism, 4-24. Hoboken, NJ: John Wiley \&Sons. https://onlinelibrary.wiley.com/doi/book/10.1002/9781118835722.

Gyogi, E. (2015). Children's agency in language choice: a case study of two JapaneseEnglish bilingual children in London. International Journal of Bilingual Education and Bilingualism, 18(6), 749-764. https://doi.org/10.1080/13670050.2014.956043.

Hadisaputra, I. N. P., \& Adnyani, N. L. P. S. (2012). The Influence of Balinese Culture on EFL University Students Speaking Ability. Lingua Scientia, 19(2), 13-26. http://dx.doi.org/10.23887/ls.v19i2.16060.

Harisal, H. (2021). Interference in Japanese Learning by First-Year Students of Hospitality Department in State Polytechnic Of Bali. Izumi, 10(1), 193-205. https://doi.org/10.14710/izumi.10.1.193-206.

Hasan, A. A. N. (2017). A phonological study of substitution in English and Arabic. Journal of College of Basic Education for Education and Human Sciences, 2017(34), 415422. https://search.emarefa.net/detail/BIM-780191.

Kroll, M. G. (2011). Engrish: A study of Japanese L1 interference in L2 English. [University of North Carolina at Pembroke]. https://libres.uncg.edu/ir/uncp/f/Matthew Kroll .pdf.

Kusumawardani, D. A. N., \& Adnyani, N. L. P. S. (2020). Interlanguage Analysis on Speech Produced by EFL Learners. Retorika: Jurnal Ilmu Bahasa, 6(2), 178-185. https://doi.org/10.22225/jr.6.2.1727.178-185.

Kutsuki, A. (2021). Do bilinguals acquire similar words to monolinguals? An examination of word acquisition and the similarity effect in japanese-english bilinguals' vocabularies. European Journal of Investigation in Health, Psychology and Education, 11(1), 168-182. https://doi.org/10.3390/ejihpe11010014.

Maheswari, P. A. M., Adnyani, N. L. P. S., \& Suwastini, N. K. A. (2020). Interlanguage analysis on Indonesian EFL learners' compositions. Lingua Didaktika: Jurnal Bahasa Dan Pembelajaran Bahasa, 14(2), 121-131. https://doi.org/10.24036/ld.v14i2.108643.

Manik, N. P. I. M. C., \& Suwastini, N. K. A. (2020). Analyzing grammatical error in students' recount text writing in junior high school. Humanis, 24(3), 238-246. https://doi.org/10.24843/jh.2020.v24.i03.p02.

Nogita, A. (2010). Do Japanese ESL learners' pronunciation errors come from inability to articulate or misconceptions about target sounds? Working Papers of the Linguistics Circle of the University of Victoria, 20(1), 82-116. https://journals.uvic.ca/index.php/WPLC/article/view/5674.

Nurita, W., \& Meidariani, N. W. (2019). Japanese Language Interference by Hotel Staf in Badung Regency in Serving Japanese Travelers. International Journal of Green Tourism Research and Applications, 1(1), 1-20. https://doi.org/10.31940/ijogtra.v1i1.1627.

Nurjaleka, L., \& Supriatnaningsih, R. (2021). In the Process of Being Bilingual of an Indonesian Child: The Phenomena of Code-Switching, Language Mixing and Borrowing. Register Journal, 14(1), 99-120. https://doi.org/10.18326/rgt.v14i1.99120.

Pratiwi, P. D., Adnyani, N. L. P. S., \& Putra, P. I. N. A. J. (2020). Native and Target L anguage Influence on Students ' Interlanguage Speech. Linguistika, 27(2), 109-122. https://ojs.unud.ac.id/index.php/linguistika/article/view/64587.

Pujiono, M., \& Nelvita. (2017). The Lexical Interference of Bataknese Language into Japanese Language amongst Students in Universitas Sumatera Utara. International 
Journal of Language and Linguistics, 4(4), 216-222. http://ijllnet.com/journals/Vol_4_No_4_December_2017/23.pdf.

Purnamasari, N. M. G., Putra, I. N. A. J., \& Suwastini, N. K. A. (2016). A descriptive study on the use of code mixing by the English teacher at SMAN Bali Mandara in the academic year 2014/2015. Lingua Scientia, 23(2), 1-8. http://dx.doi.org/10.23887/ls.v23i2.16070.

Sari, P. P. N., Budasi, I. G., Adnyani, N. L. P. S., \& Suwastini, N. K. A. (2021). the Error Analysis of Interlingual and Intralingual Interferences of the Students: a Case Study of Tourism Study Program. Lentera Pendidikan: Jurnal Ilmu Tarbiyah Dan Keguruan, 24(1), 69. https://doi.org/10.24252/lp.2021v24n1i7.

Sarif S, I., \& Suganda, D. (2020). Interferences Of English-Japanese Language In The Covid19 Pandemic. Izumi, 9(2), 121-127. https://doi.org/10.14710/izumi.9.2.121-127.

Sirbu, A. (2015). Language interference triggered by bilingualism. XVIII(1), 1-3. http://ijllnet.com/journals/Vol_4_No_4_December_2017/23.pdf.

Smith, B. (2012). Pronunciation patterns of Japanese learners and their implications for teaching. Polyglossia, 23, 199-206. https://asian-efl-journal.com/Dec_04_ko.pdf.

Suwastini, N. K. A., Wiraningsih, P., \& Adnyani, N. L. P. S. (2020). An analysis of interlanguage among EFL students' speech production in English microteaching class. Asian EFL Journal, 27(4.5), 66-89. https://doi.org/10.1111/fcre.12520.

Suwastini, N. K. A., \& Yukti, W. G. S. (2017). Errors analysis in short biography text written by the 11th grade students of a vocational high school in Singaraja. International Journal of Language and Literature, 1(1), 1-10. https://ejournal.undiksha.ac.id/index.php/IJLL/article/download/9612/6116.

Thompson, I. (2001). 'Japanese speakers.' In Learner English: A Teacher's Guide to Interference and Other Problems (pp. 296-309). Cambridge University Press. https://lib.jspi.uz/storage/uploads/files/swan-learnerenglish.pdf.

Yong, J. Y. (2001). Malay/Indonesian speaker. In Learner English: A Teacher's Guide to Interference and Other Problems (pp. 279-295). Cambridge University Press. https://doi.org/10.1017/CBO9780511667121. 